IRSH 64 (2019), pp. 4I 5-425 doi:I0.1017/So02085901900049X

(C) 2019 Internationaal Instituut voor Sociale Geschiedenis

\title{
Dissecting Sites of Punishment: Penal Colonies and Their Borders*
}

\author{
ZHANNA POPOVA \\ International Institute of Social History \\ Cruquiusweg 3I, IOI9 AT, Amsterdam, The Netherlands \\ E-mail: zhannapop@gmail.com
}

\begin{abstract}
FRANCESCA Di PASQUALE
Soprintendenza archivistica per la Sicilia, Archivio di Stato di Palermo Piazza Marina 29, 90133 Palermo, Italy
\end{abstract}

E-mail: francesca.dipasquale@beniculturali.it

\begin{abstract}
Although a crucial element of imperial architecture, non-metropolitan penal colonies remain relatively understudied, compared with the richness of historical scholarship on modern prison systems in Western Europe and its offshoots. Complementing the perspective chosen in the recent International Review of Social History Special Issue 26, "Transportation, Deportation and Exile: Perspectives from the Colonies in the Nineteenth and Twentieth Centuries", the four articles in this Special Theme propose an additional angle of investigation of the role of convicts in the incorporation of new territories into colonial empires. The authors place sites of punishment, rather than flows of convicts, at the core of their reflection, and provide a close-up analysis of circulations of information and people across the borders of penal sites on various scales: local, trans-regional, and international. They problematize the notion of "border", and consider it as a vantage point that leads to a new conceptualization of the penal colony as a system that expands in its surroundings and, in turn, assimilates external political, social, and economic stimuli. Relying on several distinct methodological approaches, the authors foreground the specificities of colonial punishment and demonstrate how punishment became part of the creation and maintenance of power inequalities between the colonies and the metropoles.
\end{abstract}

Penal colonies were a crucial element of imperial architecture. At least until the beginning of the process of decolonization, they served to incarcerate those deemed too dangerous to remain in society, to restrict and direct movements

\footnotetext{
* We would like to thank Matthias van Rossum and Klaas Stutje for this title.
} 
of local populations, and to channel the use of the forced labour of inmates to crucial infrastructural projects. Compared with the richness of historical scholarship on modern prison systems in Western Europe and its offshoots, however, non-metropolitan punitive repertoires remain relatively understudied. In this Special Theme, we seek to address the specificities of colonial punishment by dissecting several penal sites and the contexts they were embedded within. This Special Theme therefore provides a double historiographical intervention. On the one hand, it engages with the history of punishment by addressing colonial penal sites and practices and comparing and contrasting them, where possible, with the better known history of European punishment. On the other, it explores the role that penal sites and knowledge about them played in the process of nation-building both in the colonies and in the metropole.

This Special Theme thus follows the long tradition of historical research that explored punishment within larger socio-economic and political contexts. As early as 1939, Georg Rusche and Otto Kirchheimer, two researchers associated with the Frankfurt School, published Punishment and Social Structure. This was a pioneering Marxian analysis of "punishment in its specific manifestations" and the ways in which these manifestations were linked to larger phenomena in societies: modes of production, labour relations, and unemployment. ${ }^{I}$ Their work inspired a whole cohort of researchers to explore the interrelationship between types of punishment and the societies that practised them. ${ }^{2}$

Perhaps the most influential of these scholars was Michel Foucault. His elaborate theoretical framework has profoundly shaped the current academic understanding of modern punishment. Foucault had been refining his approach throughout his career, but Discipline and Punish and Madness and Civilization remained the two most influential works in this respect. Analysing the French case of the emergence of incarceration as the dominant mode of punishment, Foucault identified prisons as the main sites of punishment, where convicts were hidden from the public eye and submitted to a strict regime aimed at disciplining them. According to Foucault, the development of "the carceral" had a profound effect on society at large, spurring the wider spread of disciplinary practices and institutions, such as schools and asylums. Numerous critiques of Foucault emerged as soon as his work had been published. French scholars questioned the linearity of the transition from corporal punishment to incarceration, while researchers working on Northern Europe challenged the chronology of this transition. ${ }^{3}$ Indeed, Foucault himself was

I. Georg Rusche and Otto Kirchheimer, Punishment and Social Structure (New York, 1939).

2. For instance, David Garland, Dario Melossi, and Loï Wacquant have cited Rusche and Kirchheimer extensively.

3. For critiques of Foucault by French researchers, and his response, see Michelle Perrot (ed.), L'impossible prison: Recherches sur le système pénitentiaire au XIXème siècle (Paris, 1980), and 
extremely cautious about attempts to extrapolate his conclusions to fundamentally different contexts. ${ }^{4}$ Colonial contexts, in other words, require the elaboration of new approaches.

In the second half of the twentieth century, prison and asylum - the two most prominent places of confinement - began to attract the attention of the social sciences as well. Ample sociological and anthropological scholarship has theorized the impact of confinement on individuals. 'S Subsequently, differentiations between various historical forms of such institutions have often been blurred. Erving Goffman's influential concept of "total institution", in particular, shaped research on punishment for decades. While this concept proved to be extremely alluring due to its "analytical coherence and political force of persuasion" ${ }^{6}$ and was adopted by many social scientists and activists, historians have consistently criticized the concept of "total institution" as ahistorical and essentializing. Falk Bretschneider summarized these critiques and powerfully suggested that Goffman's concept should indeed be retired to the archives of the history of sociology rather than remain a tool of practical research. ${ }^{7}$ In this Special Theme, we take a critical distance from the notion of total institution. Although the contributors do bring up totalizing practices that were intended to shape even the most miniscule detail of the lives of inmates, they focus more on the agency of convicts, the porous quality of the colonies' borders, tensions between central and local authorities, and circulations of people and information.

In early modern times, confinement was far from dominant in the penal landscape. In Western Europe, some "proto-prisons" - monasteries and workhouses - were already in place, but long-term incarceration was considerably less widespread than corporal punishment and penal transportation. The legal and penal pluralism of the early modern times created a patchwork of localized, and often uncodified, penal practices. Globally, there existed a plethora of types of punishment, from fines and corvée labour to bodily mutilation and the death penalty. The arrival of European colonizers and their attempts to solidify their power also meant that they sought to tighten their

for an analysis of the Dutch and Northern German cases, see Pieter Spierenburg, The Prison Experience: Disciplinary Institutions and Their Inmates in Early Modern Europe (New Brunswick, NJ [etc.], I991).

4. Jan Plamper, "Foucault's Gulag", Kritika: Explorations in Russian and Eurasian History, 3:2 (2002), pp. $255^{-280}$.

5. See Erving Goffman, Asylums: Essays on the Social Situation of Mental Patients and Other Inmates (New York, 196I); Gresham M. Sykes, The Society of Captives: A Study of a Maximum Security Prison (Princeton, NJ, 2007); and David J. Rothman, The Discovery of the Asylum (New Brunswick, NJ [etc.], I97I).

6. Falk Bretschneider, "Die Geschichtslosigkeit der 'Totalen Institutionen'. Kommentar zu Erving Goffmans Studie 'Asyle' aus geschichtswissenschaftlicher Perspektive”, Wiener Zeitschrift zur Geschichte der Neuzeit, 8:1 (2008), pp. I35-142, p. I36.

7. Ibid., pp. I4I-I 42 . 
control over deployment of punishment. This often meant that penal policies became more centralized and uniform, but this did not imply the direct import of European carceral institutions into the colonies. Even in the locations where penal colonies for exiled Europeans existed, convicts of non-European origin were often subject to different types of punishment due to colonizers' ideas of their fundamental "otherness". Often, this meant that violent punishments and forced labour rather than confinement in prisons were used against the colonized populations; even in cases where prisons in the colonies did exist, they bore little resemblance to their metropolitan analogues. A variety of characteristically colonial penal institutions was created across the empires. These penal sites served not only to punish, they also had a "civilizing mission" and could become laboratories of disciplinary practices that would then be applied to the non-incarcerated colonial populations. As we will see in the articles presented here, the colonial authorities relied extensively on the forced labour of local convicts in order to reinforce their control over territories as well: convict labour in agriculture and road and railway construction became a crucial means of transforming the landscape according to the will of the authorities.

Until recently, the perception of incarceration as the dominant type of punishment and the conceptualization of prisons as hermetic institutions often directed the attention of researchers away from penal sites that did not conform to the model of "the carceral". The literature that highlighted the centrality of prison, and especially the Western European and American forms of imprisonment, has overshadowed not only the variety of the sites of confinement, but indeed other penal practices altogether. While incarceration did emerge in modern times, and in some contexts, mostly in advanced capitalist societies, did become the dominant penal practice, it frequently coexisted with other regimes of punishment, in particular convict transportation or hard labour.

In recent decades, various strands of historical research have started to address this blind spot. Global labour history has sought to overcome the conceptualization of convict labour, along with other types of unfree labour, as an aberration in the process of movement towards free wage labour. Researchers have demonstrated the crucial role of convict labour in the general process of the commodification of labour. ${ }^{8}$ Moreover, scholars of the New Imperial History have demonstrated how networks of coercion, and especially the networks of forced mobility of convicts, were built and maintained. The incorporation of colonial contexts allows one to see not only the specificities of colonial prisons, but also to see beyond the alleged triumph of incarceration 
over other penal practices. ${ }^{9}$ Lately, scholarship has underlined the role of convict transportation in empire building, as well as in the creation and maintenance of the spatial hierarchies within empires. These conclusions were consolidated in a recent Special Issue of the International Review of Social History. ${ }^{1 \circ}$ By adopting a colony-centred perspective, the authors of this Special Issue were able to highlight the crucial role of convicts and penal colonies in the imperial expansion, creation of new connections, and constant redefinition of distinctions between "colonies" and "metropoles". A particularly strong contribution to the historiography was made owing to the fact that the editors and authors focused on the multitude and complexity of convict flows, as well as on their dynamic character.

The articles presented in the current Special Theme complement this perspective by proposing an additional angle of investigation of this role of convicts in the incorporation of new territories into colonial empires. Here, the authors placed sites of punishment, rather than flows of convicts, at the core of their reflection, and provided a close-up analysis of circulations of information and people across the borders of penal sites on various scales: local, transregional, and international. In this Special Theme, the notion of "border" is problematized and becomes a vantage point that leads to a new conceptualization of the penal colony as a system that expands in its surroundings and, in turn, assimilates external political, social, and economic stimuli. The authors foreground the specificities of colonial punishment and demonstrate how punishment became part of the creation and maintenance of power inequalities

9. On colonial prisons, see, for example, David Arnold, "The Colonial Prison: Power, Knowledge and Penology in Nineteenth-Century India", in idem and David Hardiman (eds), Subaltern Studies VIII: Essays in Honour of Ranajit Guha (New Delhi, 1996), pp. 148-187; Florence Bernault, A History of Prison and Confinement in Africa (Portsmouth, 2003); Florence Bernault (ed.), Enfermement, prison, et châtiments en Afrique: du Igème siècle à nos jours (Paris, 1999); Frank Dikötter and Ian Brown, Cultures of Confinement: A History of the Prison in Africa, Asia, and Latin America (Ithaca, NY, 2003); Christien Bruinink-Darlang, Hervormingen in de koloniale periode. Verbeteringen in het Nederlands-Indisch strafstelsel in de periode 1905-1940 (Arnhem, 1993); Gabriel Haslip-Viera, Crime and Punishment in Late Colonial Mexico City, I692-I8I0 (Albuquerque, NM, I999); Patrice Morlat, La répression coloniale au Vietnam, I908-1940 (Paris, 1990); Marie Morelle and Frédéric Le Marcis, "Pour une pensée pluridisciplinaire de la prison en Afrique”, Afrique contemporaine, 253 (20I5), pp. I I7I 29; Ricardo D. Salvatore and Carlos Aguirre, The Birth of the Penitentiary in Latin America: Essays on Criminology, Prison Reform, and Social Control, I830-1940 (Austin, TX, 2010); Satadru Sen, Disciplining Punishment: Colonialism and Convict Society in the Andaman Islands (Oxford, 2000); Sylvie Thénault, Violence ordinaire dans l'Algérie coloniale, Camps, internements, assignations à résidence (Paris, 2012); Peter Zinoman, The Colonial Bastille: A History of Imprisonment in Vietnam, I862-I940 (Oakland, CA, 200I).

ıо. Christian G. De Vito, Clare Anderson, and Ulbe Bosma (eds), "Transportation, Deportation and Exile: Perspectives from the Colonies in the Nineteenth and Twentieth Centuries", International Review of Social History, $63: \mathrm{S}_{2} 6$ (2018). On the same topic, see the recent volume by Clare Anderson (ed.), A Global History of Convicts and Penal Colonies (London and Oxford, 2018). 
between the colonies and the metropoles. They do so by relying on several distinct methodological approaches.

First, the authors step aside from treating incarceration as the centre of the penal system, and consider a variety of penal practices and their overlapping. Looking at sites of punishment rather than only prisons or convict flows allows one to trace the combinations of such practices as confinement, banishment, disciplinary corporal punishments, and intra- and extramural forced labour in specific penal arrangements: a Sardinian agricultural colony; mobile forced labour camps in Senegal; New Caledonian bagne; Australian convict colonies; and a high-security Dutch colonial prison. In fact, Sardinia, as an Italian region, was not a "colonial" context in the strict sense of the term. Nevertheless, at the end of the nineteenth century, Sardinia became the preferred site for instituting penitentiary agricultural colonies, in part as a result of a "colonial" conception of that island by the Italian ruling class, which considered Sardinia a "wild", "virgin", and "empty" territory. ${ }^{I I}$ These cases clearly demonstrate that punishment in the colonial and non-metropolitan contexts implied the mobilization of multiple coercive practices against convicts.

Second, the authors problematize the notion of borders of penal sites and challenge the hermetic conception of place of confinement. They outline the moving borders of the penal sites and analyse how punitive practices could transcend not only the borders between penal sites and society, but also those between the metropole and colonies, as well as the importance of such breaches both for adjacent territories and for public opinion both in the metropole and in the colonies. This approach also provides a privileged vantage point for underlining the agency of inmates, who in the scholarship of punishment are often presented as passive objects of the repressive and disciplining policies of penal administration.

Third, the authors inscribe the penal sites not only within the local context, but also within larger ideological paradigms. They seek to be attentive to the precise realities of various punitive sites, but their research is not limited to specific locations. Rather, they use these sites - and their shifting borders as a stepping stone and reconnect these localized penal arrangements with wider political and cultural issues. The articulation of these different levels allows one to re-evaluate the role of the lesser-known penal settings in the processes of empire and nation-building. The legacy of colonial regulations affected punishment in the postcolonial period and, in turn, decolonization impacted punishment in the former colonies. In many cases, the postdecolonization newborn states inherited the general setting of the punishment

I I. Francesca Di Pasquale, “The 'Other' at Home: Deportation and Transportation of Libyans to Italy During the Colonial Era (191 I-I943)”, International Review of Social History, 63:SI26 (20I8), pp. 2 II-23I, 222. 
system from the former colonial regimes, and the process of reforming this inheritance proved protracted.

The authors of this Special Theme reflect on the relationship between the inside and the outside of penal institutions through the specific perspective of the borders of penal sites and the ways in which these borders were transgressed: convict escapes and their extramural labour, but also camp and prison inspections, visits by journalists, doctors, priests, or other informed observers. The authors elucidate this central point by addressing four different issues: escapes from penal sites and the agency of convicts; transformation of local societies and of landscape as a consequence of penal arrangements; the relationship between forced mobility and immobility within the penal context; and, finally, the influence of different social and political actors on penal policies and practices.

Each contribution in this Special Theme focuses on one or more of these and confronts different levels of analysis. The authors chiefly address the ideological dimension of the penal institutions and practices, and their discursive uses in the debates about civilization, barbarity, and belonging to the body politic. To complement this culturalist perspective, Francesca Di Pasquale analyses the (alleged) economic role of penal institutions and the output of penal labour. Romain Tiquet also discusses the interrelation between forced labour of convicts and the obligatory labour of the non-incarcerated colonial population.

The articles by Francesca Di Pasquale and Briony Neilson reflect on the entanglements between penal colonization and the process of nation-building. Throughout the imperial age, the level of "civilization" of a nation was assessed in part through comparisons of crime rates and penal practices. ${ }^{12}$ International prison conferences contributed to the circulation of ideas and debates on these themes. ${ }^{13}$ To a great extent, the discussion focused on deportation and transportation as a tool for both colonization and "civilization". This Special Theme shows how, both inside and outside European national borders, penal colonization was a cornerstone to understanding the development of the process of nation-building. As Briony Neilson demonstrates in her article, as transportation by the British to Australia was wound back, the Australian colonies, which had provided the initial inspiration for France's own penal colonial project in New Caledonia, made claims to a moral rectitude by criticizing the colonizing methods of their French neighbours, especially the bagne. While the proximity of New Caledonia aroused moral panic in the Australian colonial press about the destructive potential of an invasion of escaped or freed French convicts, the presence of the French penal colony actually served very constructive ideological and political

I 2. John Pratt, Punishment and Civilization: Penal Tolerance and Intolerance in Modern Society (London, 2002).

I3. Briony Neilson, "The Paradox of Penal Colonization: Debates on Convict Transportation at the International Prison Congresses 1872-1895”, French History and Civilization: News and Papers from the George Rudé Seminar, 6 (2015), pp. 198-2 I I. 
ends in enabling the Australian colonies to distance themselves from their own convict past as a receptacle for transported British felons.

During the process of decolonization, a number of states employed penal systems in order to fight political opponents and to strengthen the authority of the national government. Some regimes adopted forms of violence in the penal arena inherited from the colonizers, such as corporal punishment and forced labour. Both in Africa and in Indonesia the regimes established in the postcolonial period resorted to forced labour on a massive scale. ${ }^{I 4}$

Penal colonies both in Sardinia and New Caledonia contributed to mark the realm of citizenship rights and to strengthen national identity. They helped to create imperial hierarchies of territories and populations, establish and maintain control, but also marked the limits of colonial power. Penal colonies had a multitude of functions in the imperial contexts, but, as the authors convincingly demonstrate, they were far from being locations under the absolute control of the authorities. Discussions around penal sites triggered the circulation of information, which cut across the boundaries between "centre" and "periphery" of the imperial landscape. The article by Klaas Stutje provides an example of such discursive circulation. The author discusses the Dutch colonial prison camp on the Indonesian island of Nusakambangan and demonstrates how outside commentators have created a plethora of representations of this penal site. By analysing a selection of press articles about the island, Stutje highlights the construction of the image of the penal colony by journalists and writers of various political persuasions. He also shows how these images were then used as arguments in wider discussions about Dutch colonial power in Indonesia, and its limits.

Penal institutions and penal labour were used to modify the environment both inside and outside the penal territory. In particular, as Romain Tiquet highlights in his article about mobile labour camps in Senegal under French colonial rule, in the colonial context the forced labour of convicts was the foundation of the economic policies implemented by the colonizers. Principally employed to build infrastructure, the work of prisoners contributed to altering the landscape of the former European colonies, transforming those territories in an (almost) irreversible way. However, recourse to penal labour to tame "virgin" territories was not a peculiarity of the colonial economy. Rather, as the article by Francesca Di Pasquale underlines, penal colonization was used to reclaim lands also in Europe. Penal colonies in non-metropolitan contexts, for instance on Sardinia, could also be used as laboratories for disciplinary and punitive practices that could later be "imported" to the metropoles. Di Pasquale's analysis of penal labour shows particularly clearly the interconnections and mutual influences between 
these different contexts in the Italian case. In a broader perspective, as the authors underline, penal colonies were in both contexts a tool of social engineering used to tame both convicts and free people, and to mould them in accordance with a precise social model that relied on the concepts of industrial productivity and strict labour ethic. ${ }^{\text {Is }}$

Entanglements between colonies and metropole also emerge when we observe the juxtaposition of the mobility and immobility of penal practices. As Romain Tiquet underlines with regard to mobile penal camps in colonial Senegal, convicts were forced into perpetual mobility as part of the maintenance of colonial infrastructure. In this French colony, prisoners and camps were constantly moved following the development of roadworks. Mobile camps served not only as tools to force convicts to work, they were installed also in response to the international criticism of obligatory labour among the colonial population at large (the prestation system). Tiquet highlights the agency of the prisoners of these camps. As he explains, prisoners could resist this penal practice not only by attempting to escape, which constituted "an intentional form of mobility", but also through forms of immobility, namely by intentionally injuring themselves in order to be transferred to civil prisons. Forced mobility as the organizing principle of penal colonies was not an exclusively colonial phenomenon. At the beginning of twentieth century, in the Italian penal colony of Castiadas, three "mobile houses" were used to reduce the time that convicts usually needed to reach the workplace from their barracks. Forced labour was at the core of such mobile penal colonies. In this perspective, the colony was no longer just a place, "but a principle of managed mobilities, mobilizing and immobilizing populations, dislocating and relocating peoples according to a set of changing rules and hierarchies that orders social kinds". This principle "does not occur in a given, fixed designated space" but in a place where the borders constantly shifted. ${ }^{16}$

The four articles in this Special Theme show the relevance of an analysis of punishment that transcends the borders between penal sites and society as well as between the metropole and colonies. The authors started at the local level of specific locations, and then problematized the concept of borders of penal sites and highlighted the plethora of exchanges and mutual influences through which these borders could be transgressed. They convincingly demonstrated that penal colonies were not hermetically sealed from their surroundings, but were instead deeply entangled with their territorial, social and political contexts, and played a role both in the process of empire and nation building and in the global history of punishment.

I s. Dario Melossi and Massimo Pavarini, The Prison and the Factory: Origins of the Penitentiary System (London [etc.], i98I).

I6. Ann Laura Stoler, “Colony”, Political Concepts, I (201 I), available at: http://www.politicalconcepts.org/issuei/colony/; last accessed I4 December 2017. 


\section{TRANSLATED ABSTRACTS \\ FRENCH - GERMAN - SPANISH}

Zhanna Popova et Francesca Di Pasquale. En disséquant les sites de la peine: les colonies pénitentiaires et leurs frontières.

Bien qu'elles aient été un élément crucial de l'architecture impériale, les colonies pénitentiaires non métropolitaines restèrent relativement sous-étudiées par comparaison avec la richesse de l'érudition historique sur les systèmes pénitentiaires modernes en Europe occidentale et ses ramifications. Complétant la perspective choisie dans le numéro spécial 26 de l'International Review of Social History, "Transfert, déportation et exile: perspectives des colonies aux dix-neuvième et vingtième siècles", les quatre articles contenus dans ce Thème Spécial proposent un angle supplémentaire pour étudier le rôle des bagnards dans l'incorporation de nouveaux territoires dans les empires coloniaux. Les auteures placent au cœur de leur réflexion la peine plutôt que les flux de bagnards, et présentent une analyse fouillée des circulations de l'information et des personnes au-delà des frontières des sites pénitentiaires à diverses échelles: locale, transrégionale et internationale. Elles problématisent la notion de "frontière", et la considèrent comme un point d'observation qui conduit à une nouvelle conceptualisation de la colonie pénitentiaire en tant que système qui s'étend dans son environnement, puis assimile les stimuli externes politiques, sociaux et économiques. Se fondant sur plusieurs approches méthodologiques distinctes, les auteures mettent au premier plan les spécificités de la peine coloniale, et démontrent comment la peine devint une partie de la création et du maintien des inégalités de pouvoir entre les colonies et les métropoles.

Traduction: Christine Plard

Zhanna Popova und Francesca Di Pasquale. Strafstätten analysieren: Strafkolonien und ibre Grenzen.

Nicht-metropolitane Strafkolonien sind zwar ein ausschlaggebender Bestandteil imperialer Strukturen, doch die Forschung hat sich vergleichsweise wenig mit ihnen befasst, wohingegen es eine Fülle historischer Untersuchungen moderner Gefängnissysteme in Westeuropa und seinen Ablegern gibt. Die vier Beiträge zu diesem Schwerpunkt ergänzen die in Sonderheft 26 der International Review of Social History ("Verschickung, Deportation und Exil: Perspektiven aus den Kolonien des 19. und des 20. Jahrhunderts") gewählte Perspektive und schlagen einen weiteren Ansatz vor: die Untersuchung der Rolle, die Sträflinge bei der Eingliederung neuer Territorien in Kolonialreiche spielen. Im Mittelpunkt der von den Autoren angestellten Überlegungen stehen nicht so sehr Sträflingsströme als Strafstätten. Geboten werden genaue Analysen der Zirkulation von Informationen und Menschen über die Grenzen von Strafstätten hinweg, und das auf verschiedenen Ebenen: lokal, transregional und international. Die Autoren problematisieren die Vorstellung von "Grenzen"; sie behandeln diese Vorstellung als Ausgangspunkt für eine neue Konzeptionalisierung der Strafkolonie als System, das sich in seiner Umgebung ausbreitet und äußere politische, gesellschaftliche und wirtschaftliche Impulse assimiliert. Gestützt auf eine Reihe unterschiedlicher methodologischer Ansätze betonen die Autoren die Besonderheiten des kolonialen Strafvollzugs und zeigen, 
wie der Strafvollzug Teil der Herstellung und des Erhalts von Machtungleichheiten wurde, sowohl in den Kolonien als auch in den Metropolen.

Übersetzung: Max Henninger

Zhanna Popova y Francesca Di Pasquale. Diseccionando los lugares de castigo: las colonias penales $y$ sus fronteras.

A pesar de que eran un elemento crucial en el diseño de la arquitectura imperial, las colonias penales no metropolitanas son todavía objeto de escasos estudios en comparación con la riqueza de los trabajos históricos dedicados a los modernos sistemas de prisión en Europa occidental y sus ramificaciones. De forma complementaria a la perspectiva propuesta en el reciente número especial 26 de la International Review of Social History, "Desplazamiento, deportación y exilio: perspectivas desde las colonias en los siglos XIX y XX", los cuatro artículos de este Tema Especial proponen un ángulo adicional desde el que investigar el papel de los convictos en la incorporación de los nuevos territorios en los imperios coloniales. En el punto central de la reflexión los/las autores/as sitúan los espacios de castigo más que los flujos de presos y proporcionan un análisis detallado de la circulación de información y de personas que traspasaban los límites de los espacios penales en diversa escala: local, transregional e internacional. En los textos se problematiza la noción de "límite" (border) y lo consideran como un punto de observación privilegiado para desarrollar una nueva conceptualización en referencia a las colonias penales como un sistema que se expande hacia sus alrededores $\mathrm{y}$, en sentido contrario, asimila estímulos políticos, sociales y económicos externos. A partir de diferentes aproximaciones metodológicas los/las autores/as sitúan en primer plano las especificidades del sistema colonial de castigo y demuestran como ese castigo llegaba a ser parte de la creación y reproducción de las desigualdades de poder existentes entre las colonias y las metrópolis.

Traducción: Vicent Sanz Rozalén 